\title{
SCREENING FOR PENICILLIN PLASMA RESIDUES IN CATTLE BY ENZYME-LINKED IMMUNOSORBENT ASSAY
}

\author{
H.J. LEE, P.D. RYU, H. LEE, M.H. CHO, M.H. LEE* \\ College of Veterinary Medicine and School of Agricultural Biotechnology, \\ Seoul National University, Suwon 441-744, Korea \\ Received June 19, 2000 \\ Accepted August 28, 2001
}

Abstract

Lee, H. J., P. D. Ryu, H. Lee, M. H. Cho, M. H. Lee:Screening for Penicillin Plasma Residues in Cattle by Enzyme-Linked Immunosorbent Assay. Acta Vet. Brno 2001, 70: 353-358.

In this study, we established a rapid prediction test for the detection of the cattle with violative tissue residues of penicillins. The recommended therapeutic doses of two penicillins, ampicillin (withdrawal time, 6 days) and amoxicillin (withdrawal time, 14 days), were administered to two groups of 10 cattle each. Blood was sampled and tested before drug administration and during the withdrawal period. The concentration of penicillins in plasma, determined by a semi-quantitative ELISA, was compared to that of internal standard ( $4 \mathrm{ppb}$ as penicillin $\mathrm{G})$. The absorbance ratio of internal standard to sample (B/Bs) was introduced as an index to determine whether drug residues in cattle tissues are negative or positive. That means $\mathrm{B} / \mathrm{Bs}$ ratio lower than 1 was considered residue positive and that higher than 1 negative.

All 10 plasma samples from non-treated cattle showed negative results for both penicillins. Both penicillins were detected in plasma samples of cattle treated until the 3rd day of withdrawal period.

The present study has shown that the semi-quantitative ELISA could be easily adapted for prediction of screening plasma residues for penicillin antibiotics (ampicillin and amoxicillin) in live cattle.

Penicillin ELISA, plasma, cattle contamination, live animal test

With the ever-growing world population, animal production practices have become more intensive and efficient, accompanied by increasing demands for drug treatment. Currently, approximately $80 \%$ of all food animals receive medication for part or most of their lives (Sterne sjö et al. 1998). In the near future, nearly all animals bred in the world for food will receive chemotherapeutic and prophylactic agents of some type (Booth 1988). A survey of all violative carcasses in the United States in 1993 revealed that the most frequent drug residues were penicillin (20\%), streptomycin (10\%), oxytetracycline (10\%), and sulfamethazine (9\%) (Paige 1994). According to Canadian Animal Health Institute, penicillins were the most frequently detected residues in milk in most countries (Heeschen et al. 1996). Since 1986, Department of Veterinary Service, Ministry of Agriculture \& Forestry, Korea has conducted National Residue Program (NRP) to sample meat and poultry for residue tests at the slaughtering establishments under its inspection authority and from import shipments at the port of entry. In 1997, a total of 45,000 samples comprising 10,000 beef, 23,000 pork, and 11,000 poultry meat were analyzed for five kind of antibiotics (penicillins and tetracyclines) and six sulfonamides. The results showed violative residues of tetracyclines, sulfonamides and aminoglycosides in beef, pork, and poultry meat.

A few cases of minor allergic reactions (e.g., skin rashes) in individuals previously sensitized to penicillin $G$ residues in milk and meat have been documented, as well as strong evidence linking a widespread agricultural use of antibiotics to an increase in antibiotic resistance among the animal and human pathogens (Dewdney et al. 1984;

Address for correspondence:

$\begin{array}{ll}\text { Mun-Han Lee, DVM, Ph.D. } & \text { Phone: }+88-31-290-2741 \\ \text { Laboratory of biochemistry } & \text { Fax: }+88-31-293-0084\end{array}$

College of Veterinary Medicine, Seoul National University

Suwon 441-744, Korea

Phone: +88-31-290-2741
E-mail: vetlee@ @snu-ack

http://www.vfu.cz/acta-vet/actavet.htm 
Franco et al. 1990; Huber 1971; Kindred et al. 1993; Mitchell et al. 1995; Ormerod et al. 1987).

The demands for reliable, simple, sensitive, rapid and low-cost methods for detecting residues in foods continue to grow (Mitchell et al. 1998; Lee et al. 2001). Variety of enzyme immunoassays have been developed and adopted for detecting the generic groups of chemical residues in milk, urine, blood, and meat samples (Gardner et al. 1996; Szekacs 1994; Lee et al. 2000; Lee et al. 2001). Enzyme-linked immunosorbent assay (ELISA) has become the most popular method for chemical residue detection in food due to its extreme sensitivity, simplicity, and ability to screen large number of samples (Clifford 1985; Gardner et al. 1996; Szekacs 1994; Lee et al. 2001).

In the present study, we developed a live animal test to predict the tissue residues of penicillins (ampicillin and amoxicillin) in cattle by examining the concentration of drug in blood during the withdrawal period obtained by an ELISA technique.

\title{
Materials and Methods
}

Materials

Ten Holstein female cattle ( 7 - 8 month old, mean body mass $200 \mathrm{~kg}$ ) were used in the experiments. Binotal Injection $(100 \mathrm{mg} / \mathrm{ml}$ ampicillin natrium) was obtained from Bayer Korea Ltd. (Seoul, Korea). Clamoxyl L.A. Injection $(150 \mathrm{mg} / \mathrm{ml}$ amoxicillin trihydrate) was obtained from Pfizer Korea Ltd. (Seoul, Korea). ELISA kits for B-lactams, manufactured by Idetek, were purchased from Korea Media Ltd.

Drug administration and samples

Ampicillin was administered intramuscularly to each of the 10 cattle at the rate of $11 \mathrm{mg}$ per kg body weight per day for seven consecutive days, and amoxicillin twice ( $24 \mathrm{~h}$ interval) intramuscularly to each of $10 \mathrm{cattle}$ at $15 \mathrm{mg}$ per kg body weight. Blood samples were collected from all cattle before administration of the drugs and on days 1 , $3,5,6$, and 10 after the last ampicillin injection. From the cattle treated with amoxicillin, blood samples were collected on days $1,3,7,10$, and 14 . Ten $\mathrm{ml}$ of blood from each cattle were collected in heparinized tubes and centrifuged at $4500 \times g$ for 10 minutes to collect the plasma.

Preparation of standard curves

Stock standard solution of $1000 \mu \mathrm{g} / \mathrm{ml}$ of each ampicillin and amoxicillin were prepared using USP standards in saline. These stock solutions were further diluted with saline or blank serum to prepare $0,1,2,5,10,20,50,100$, 500 , and $1000 \mu \mathrm{g} / \mathrm{ml}$ working standard solutions. Standard curves of each antibiotic were constructed using the standard solutions fortified into serum to determine the detection limit for the ELISA kit.

\begin{abstract}
Analysis of penicillins in plasma
ELISA tests for $\beta$-lactams were applied to each plasma sample in duplicate using a modified methodology described by B oi on et al. (1995), in which the manufacturer's protocol for milk screening was adapted for plasma screening. Briefly, $250 \mu \mathrm{l}$ of the internal standard solution (equivalent to $4 \mathrm{ppb}$ penicillin $\mathrm{G}$ ) was pippetted into a test tube containing immobilized $\beta$-lactam antibodies. The plasma $(250 \mu$, diluted $1: 10 \mathrm{w} / \mathrm{PBS})$ was pippetted into individually labeled tubes. An equal volume of tracer solution (enzyme conjugate, lyophilized horseradish peroxidase labeled $\beta$-lactam conjugate with preservative) was added, and the test tubes were incubated at room temperature for 3 minutes with continuous shaking. The excess sample and conjugate reactants were then washed out with saline. A colour developer ( $0.5 \mathrm{ml}$, enzyme substrate) made up of 2,2'-azino-bis(3-ethylbenzothiazoline6 -sulfonic acid) and hydrogen peroxide in citrate buffer was added to the test tubes, and the mixture was incubated at room temperature for 3 minutes with continuous shaking. Dilute sodium dodecyl sulfate solution $(0.5 \mathrm{ml})$ was added to each test tube to stop the reaction. The absorbance was read at the wavelength of $405 \mathrm{~nm}$ with a photometric detector (Idetek Reader, Awareness Technology, Inc., USA, operated in the 0.9 ratio mode) and compared with that of the internal standard $(4 \mathrm{ppb})$. Samples with absorbance higher than that of the internal standard were considered to be negative ( $\beta$-lactam drug free), and those with absorbance lower than that of the internal standard were considered as positive. In this analysis, no more than 5 samples were processed simultaneously, and the assay was completed within 10 minutes (B ois on et al. 1995; Cullor et al. 1994).
\end{abstract}

\section{Results}

Standard curves and detection limits

The standard curves of ampicillin and amoxicillin were constructed to determine the detection limits of each drug. The detection limits of ampicillin and amoxicillin were found to be lower than 1 ppb based on the B/Bo ratio of 0.8 in the ELISA system (Figs. 1 and 2). 


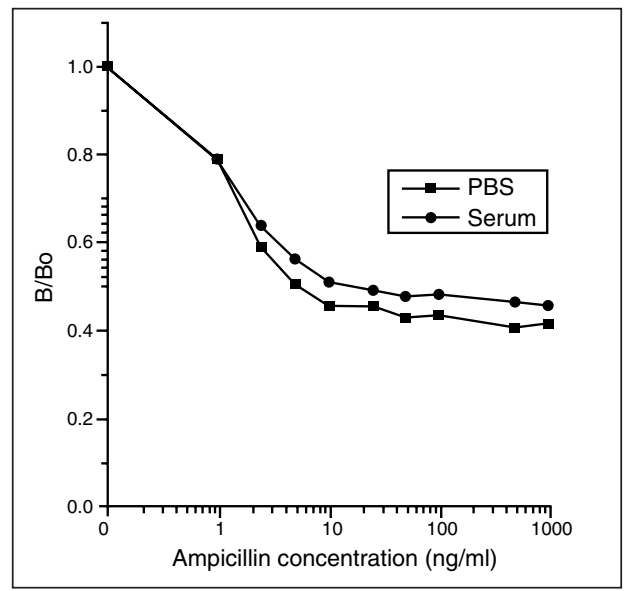

Fig. 1. Standard curves of ampicillin in phosphate buffer solution (PBS) and serum. Detection limit of ampicillin was calculated as less as $1 \mathrm{ppb}$. The detection limit of ELISA kit was determined as the point of the $\mathrm{B} / \mathrm{Bs}$ ratio of 0.8 . B/Bo: Absorbance ratio of the standard (Bo) and PBS or control serum (B).

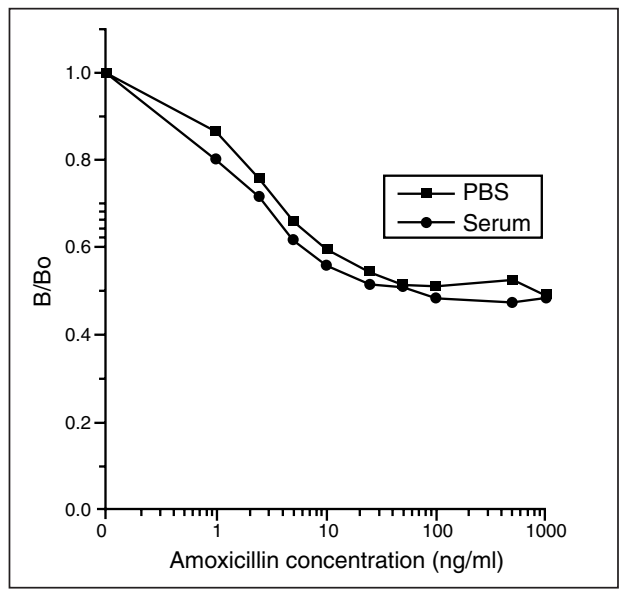

Fig. 2. Standard curves of amoxicillin in phosphate buffer solution (PBS) and serum. Detection limit of amoxicillin was calculated as less as $1 \mathrm{ppb}$. The detection limit of ELISA kit was determined as the point of the $\mathrm{B} / \mathrm{Bs}$ ratio of 0.8 . B/Bo: Absorbance ratio of the standard (Bo) and PBS or control serum (B).

\section{Live animal test for penicillins in plasma}

Ampicillin. Results of plasma analysis are shown in Table 1. As the absorbance ratios of normal 10 cattle of the control group were higher than 1.0, that is, the concentrations of ampicillin in the diluted plasma $(\times 10)$ of this group were higher than $4 \mathrm{ppb}$, the control group was negative. On day 1 of withdrawal, 8 of the 10 samples were found positive. The number of positive samples on day 3 was 5 . All samples showed negative reaction after day 5 of withdrawal $(\mathrm{B} / \mathrm{Bs}$ ratio $\geq 1.0)$.

Table 1

Depletion profile of ampicillin in plasma during withdrawal period

\begin{tabular}{|c|c|c|c|}
\hline $\begin{array}{c}\text { Withdrawal } \\
\text { (days) }\end{array}$ & $\begin{array}{c}\text { No. of } \\
\text { positive }\end{array}$ & $\begin{array}{c}\text { No. of } \\
\text { negative }\end{array}$ & $\begin{array}{c}\text { B/Bs ratio } \\
\text { (Mean } \pm \text { SEM) }\end{array}$ \\
\hline Control* $^{*}$ & 0 & 10 & $1.374 \pm 0.079$ \\
1 & 8 & 2 & $0.818 \pm 0.171$ \\
3 & 5 & 5 & $1.126 \pm 0.457$ \\
5 & 0 & 10 & $1.409 \pm 0.119$ \\
6 & 0 & 10 & $1.443 \pm 0.070$ \\
\hline
\end{tabular}

* Blood was collected before administration of ampicillin.

The drug was administered intramuscularly with $11 \mathrm{mg} / \mathrm{kg}$ body weight once daily for seven consecutive days, and blood samples were collected from cattle during the withdrawal period. Concentration of ampicillin in plasma was analyzed using a LacTek ELISA kit. B is absorbance of sample and Bs is absorbance of the internal standard (4 ppb). B/Bs ratio lower than 1.0 is considered positive and that higher than 1.0 negative.

Amoxicillin. Results of plasma analysis are shown in Table 2. As the absorbance ratios of normal 10 cattle of the control group were higher than 1.0, that is, the concentrations of amoxicillin in the diluted plasma $(\times 10)$ of this group were higher than $4 \mathrm{ppb}$, the group tested negative. All samples tested positive on day 1 of withdrawal. On day 3,4 of the 10 samples were positive. After day 5 of withdrawal, all samples showed negative reaction (B/Bs ratio $\geq 1.0)$. 
Table 2

Depletion profile of amoxicillin in plasma during withdrawal period

\begin{tabular}{|c|c|c|c|}
\hline $\begin{array}{c}\text { Withdrawal } \\
\text { (days) }\end{array}$ & $\begin{array}{c}\text { No. of } \\
\text { positive }\end{array}$ & $\begin{array}{c}\text { No. of } \\
\text { negative }\end{array}$ & $\begin{array}{c}\text { B/Bs ratio } \\
\text { (Mean } \pm \text { SEM) }\end{array}$ \\
\hline Control* & 0 & 10 & $1.405 \pm 0.145$ \\
1 & 10 & 0 & $0.760 \pm 0.082$ \\
3 & 4 & 6 & $1.255 \pm 0.173$ \\
5 & 0 & 10 & $1.436 \pm 0.171$ \\
7 & 0 & 10 & $1.472 \pm 0.150$ \\
10 & 0 & 10 & $1.413 \pm 0.081$ \\
\hline
\end{tabular}

* Blood was collected before administration of amoxicillin.

The drug was administered twice intramuscularly with $15 ? / \mathrm{kg}$ body weight at intervals of $24 \mathrm{~h}$ and blood samples were collected from cattle during withdrawal period. Concentration of amoxicillin in plasma was analyzed using a LacTek ELISA kit. B is absorbance of sample and $\mathrm{Bs}$ is absorbance of the internal standard (4 ppb). B/Bs ratio lower than 1 is considered positive and that higher than 1 negative.

\section{Discussion}

To prevent unwanted drug residues from entering the human food chain, both the government authorities and the industries have established extensive control measures (Sternesjö et al. 1998). A variety of rapid screening tests have been developed and applied for determining drug contamination of animal products on farms and slaughterhouses. The Swab Test On Premises (STOP), a nonspecific microbial inhibition test, has been used in abattoirs in the United States and Canada for over 10 years to screen for antibiotic residues in tissues from slaughtered animals (Korsrud et al. 1998). The test requires overnight incubation, and results are not ready until the following day.

Sweeney et al. (1993) developed a model with urine of pigs to predict the number of days for sulfamethazine concentration to fall below $0.1 \mathrm{ng} / \mathrm{g}$ of tissue residues in various organs. This prediction model provided the practical basis for current Sulfa On Site (SOS) test in which swine urine is used for screening sulfonamide residues in animal tissue in federally inspected abattoirs of the United States, Canada, and Korea. With the correlation between residue levels in tissue and urine established, the urine residue is used as an indicator of sulfamethazine in animal tissue. Though, unlike STOP and the Live Animal Swab Test, the SOS test provides same-day results, and it detects only sulfonamides. Papich et al. (1994) conducted experiments to determine whether penicillin residues in the plasma of live animals can be used as a practical indicator of penicillin residues in tissues of food-producing animals at slaughter. According to the results, penicillin $\mathrm{G}$ in the plasma did not correlate with that in tissues. To determine whether commercially available rapid tests can be used as screening tests to indicate the presence of penicillin $\mathrm{G}$ in the plasma of live animals, B oison et al. (1995) analyzed plasma from healthy steers injected with procaine penicillin $\mathrm{G}$ only, and a combination using benzathine penicillin $\mathrm{G}$ with four commercially available tests (Brilliant Black reduction test, LacTek test, Charm Farm test, and Charm Test II receptor assay). When results of the four rapid tests were compared with the results of liquid chromatographic method, none of the rapid tests gave false-positive results. With the administered dosage taken into consideration, plasma concentration profiles of penicillin antibiotics in our study were similar to the above studies.

As the withdrawal time of a drug is established based on the tolerance level in tissue and elimination rate of the drug, and blood is a central pool of drug distribution to body compartments and elimination from tissues through biological fluids (B ooth 1988), it may be help to predict the residue of drugs in tissue by examining the blood drug depletion profile 
during withdrawal period (Korsrud et al. 1995; B ois on et al. 1995; Lee et al. 2000; Lee et al. 2001). According to our results, the developed methods can be adapted easily to predetect residues of penicillin antibiotics (ampicillin and amoxicillin) in live cattle using diluted blood plasma $(\times 10)$ with the modified ELISA test kits.

It is conceivable that the veterinary inspector in the abattoir may be able to use this method to screen for penicillin antibiotics in plasma from live cattle in holding pens prior to slaughter and obtain same-day results. Cattle that show positive can then be held in the pens until retest results come up negative before they are slaughtered.

\section{Aplikace metody ELISA pro stanovení penicilínovích reziduí v krevní plasmě skotu}

V této studii byl vypracován postup pro detekci prchavých zbytků penicilínu v tkanivách skotu. Doporučované dávky dvou penicilínů, jmenovitě ampicilínu (doba odbourání 6 dní) a amoxicilínu (doba odbourání 14 dní) byly podány dvěma skupinám skotu $(\mathrm{n}=10)$. Krev byla odebrána a testována před podáním léků i počas jejich odbourávání. Koncentrace penicilínu $\mathrm{v}$ plasmě byla stanovena pomocí semikvantitativní metody ELISA a byla porovnána $\mathrm{s}$ koncentrací interního standardu (4ppb penicilínu G). Poměr absorbance interního standardu k absorbanci vzorky (B/Bs) byl definován jako index k určení či zbytek antibiotik ve tkáních byl pozitivní anebo negativní. Poměr B/Bs menší než 1 byl pokládán jako reziduálně pozitivní a poměr vetší než 1 jako reziduálně negativní.

Každý z deseti vzorků odebraných skotu, jemuž nebylo podáno žádne antibiotikum byl negativní na oba penicilíny. Oba však byly detekovány v plasmě zvířat do třetího dne od podání dávky.

Táto studie potvrdila, že semikvantitativní metoda ELISA může být snadno adaptována pro stanovení reziduí antibiotik penicilínové řady (ampicilínu a amoxicilínu) v krevní plasmě skotu.

\section{Acknowledgements}

This work was supported by the Brain Korea 21 Project and a grant from Agricultural Research and Promotion Center.

\section{References}

BOISON, J. O., KORSRUD, G. O., PAPICH, M. G., MACNEIL, J. D. 1995: Comparison of four commercially available rapid test kits with liquid chromatography for detecting penicillin $\mathrm{G}$ residues in bovine plasma. J. Assoc. Off. Anal. Chem. Int. 78: 1144-1152

BOOTH, N. H.1988: Veterinary pharmacology and therapeutics. In: BOOTH, N. H., MCDONALD, L. E.: Toxicology of drug and chemical residues. Iowa State University Press, Ames, Iowa, pp. 1149-1205

CUllor, J. S., VAN EENENNAAM, A., GARDNER, I., PERANI, L., DELLINGER, J., SMIT, W. L., THOMPSON, T., PAYNE, M. A., JENSEN, L., GUTERBOCK, W. M.1994: Performance of various tests used to screen antibiotic residues in milk samples from individual animals. J. Assoc. Off. Anal. Chem. Int. 77: $862-870$

DEWDNEY, J. M., EDWARDS, R. G. 1984: Penicillin hypersensitivity is milk a significant hazard?: a review. J. Rech. Soc. Med. 77: 866-877

FRANCO, D. A., WEBB, J., TAYLOR, C. E. 1990: Antibiotic and sulfonamide residues in meat: implications for human health. J. Food Prot. 53: 178-185

GARDNER, I. A., CULlOR, J. S., GALEY, F. D., SISCHO, W., SALMAN, M., SLENNING, B., ERB, H. N., TYLER, J. W.1996: Alternatives for the validation of diagnostic assays used to detect antibiotic residues in milk. J. Am. Vet. Med. Assoc. 209: 46-52

HEESCEN, W. H., SUHREN, G. 1996: Principles of and practical experiences with an integrated system for the detection of antimicrobials in milk. Milchwissenschaft. 51: 154-164

HUBER, W. G.1971: The impact of antibiotic drugs and their residues. Adv. Vet. Sci. Comp. Med. 15: 101-132

KINDRD, T. P., HUBBERT, W. T. 1993: Residue prevention strategies in the United States. J. Am. Vet. Med. Assoc. 202: 46-49

KORSRUD, G. O., SALIBURY, C.D. C., FESSER, A. C. E., MACNEIL, J. D. 1995: Laboratory evaluation of the Charm Farm test for antimicrobial residues in meat. J. Food Prot. 58: 1129-1132

KORSRUD, G. O., SALISBURY, C. D. C., RODES, C. S., PAPICH, M. G., YATES, W. D. G., BULMER, W. S., 
MACNEIL, J. D., LANDRY, D. A., LAMBERT, G., YONG, M. S., RITTERS, L. 1998: Depletion of penicillin $\mathrm{G}$ residues in tissues, plasma and injection sites of market pigs injected intramuscularly with procaine penicillin G. Food Addit. Contam. 15: 421-426

LEE, H. J., LEE, M. H., HAN, I. K. 2001: Application of ELISA for the detection of oxytetracycline residue in live animal. Asian-Aust. J. Anim. Sci. 14: 378-381

LEE, H. J., LEE, M. H., HAN, I. K. 2000: Application of ELISA for the detection of penicillin antibiotic residues in live animal. Asian-Aust. J. Anim. Sci. 13: 1604-1608

LEE, H. J., LEE, M. H., RYU, P. D., LEE, H., CHO, M. H. 2001: Enzyme-linked immunosorbent assay for screening the residues of tetracycline antibiotics in pigs. J. Vet. Med. Sci. 63: 553-556

LEE, M. H., LEE, H. J., RYU, P. D. 2001: Public health risks: chemical and antibiotic residues. Asian-Aust. J. Anim. Sci. 14: 402-413

MITCHELL, J. M., YEE, A. J. 1995: Antibiotic use and transfer of drug resistance: does it mean we should stop treating animals with these drugs? Dairy Food Environ. Sanit. 15: 484-487

MITCHELL, J. M., GRIFFITHS, M. W., MCEWEN, S. A., MCNAB, W. B., Yee, A. J. 1998: ntimicrobial drug residues in milk and meat: causes, concerns, prevalence, regulations, tests, and test performance. J. Food Prot. 61: $742-56$

ORMEROD, A. D., REID, T. M. S., MAIN, R. A. 1987: Penicillin in milk-its importance in urticaria. Clin. Allergy. 17: $229-234$

PAIGE, J. C. 1994: Analysis of tissue residues. FDA Vet. 9: 4-6

PAPICH, M. G., KORSRUD, G. O., BOISON, J. O., YATES, W. D., MACNEIL, J. D., JANZEN, E. D., MCKINNON, J. J., LANDRY, D. A. 1994: Disposition of penicillin G after administration of benzathine penicillin $\mathrm{G}$, or a combination of benzathine penicillin $\mathrm{G}$ and procaine penicillin $\mathrm{G}$ in cattle. Am. J. Vet. Res. 55: $825-30$

STERNESJÖ, L., JOHNSSON, G. 1998: A Novel Rapid Enzyme Immunoassay (Fluorophos BetaScreen) for Detection of B-Lactam Residues in Ex-Farm Raw Milk. J. Food Prot. 61: 808-811

SWEENEY, R. W., BARDALAYE, P. C., SMITH, C. M., SOMA, L. R., UBOH, C. E. 1993: Pharmacokinetic model for predicting sulfamethazine disposition in pigs. Am. J. Vet. Res. 54: 750-754

SZEKACS, A. 1994: Development of enzyme-linked immunosorbent assay (ELISA) systems for environmental monitoring. Acta Biol. Hung. 45: 77-80 